\title{
A HATÁR MENTI TERÜLETEK JELLEGZETESSÉGEINEK ÁTALAKULÁSA A 20. SZÁZAD VÉGI NYUGAT-MAGYARORSZÁGON
}

\author{
(The Transformation of the Characteristics of Border Regions at \\ the End of the $20^{\text {th }}$ Century in West Hungary)
}

\author{
HARDI TAMÁS - NÁRAI MÁRTA
}

Kulcsszavak:

osztrák-magyar határ határmentiség határ menti együttmúködés

Magyarország nyugati határa, az osztrák-magyar államhatár az elsỏ világháborút lezáró békerendszerben született meg, hasonlóan Magyarország többi államhatárához. Azonban történeti fejlödésében, jellegzetességeiben lényeges eltéréseket találunk. A két világháború közötti idöszakban, mikor a környezö, ujonnan alakult vagy frissen átalakult nemzetállamok (a kis-antant országok) az új határok elválasztó szerepének fokozására törekedtek nyugati határunk átjárható maradt, Magyarország és Ausztria között a határ nem jelentett akadályt a mindennapi kapcsolatok folytatásában. A szocializmus időszaka alatt azonban ez a határvonal két nagy világrendszer elválasztó gátjává vált, $s$ a szigoruan örzött határterületek kimaradtak fontos fejlesztési programokból, s a korábban hagyományosan fejlett térségek periférikus helyzetbe kerültek. Az 1989-1990. évi rendszerváltás után a térség helyzete ismételten felértékelödött, s mára az osztrákmagyar határmente jelentös része az ország gazdasági fejlödésének élenjáró területévé vált. Tanulmányunk ennek az utolsó évtizednek a változásait kivánja bemutatni korábbi kutatások eredményeit felhasználva. Szólunk az átalakuló gazdaságról, összehasonlítva azt a szomszédos osztrák terulletek (Burgenland) fejlödési irányaival; a társadalmi atalakulásról; a határon átnyúló kapcsolatok megváltozásáról és a jövóbéli lehetöségekrôl.

\section{Bevezetö}

A határ mentén elhelyezkedỏ területek a regionális tudomány kitüntetett érdeklödését mondhatják magukénak. Különleges a maga nemében, mert nem lehet a „határ menti térség” fogalmát minőségi jellemzókkel körülírni, csupán az az egy kritérium érvényes rá, hogy valamely államhatár hatása érezhetỏ a térség mindennapi életében, gazdaságának, társadalmának fejlődésében, főbb jellemzőiben. Így minden határ menti terület önmagában sajátos fejlỏdést felmutató térség, amelyet a regionális tudománynak mélyrehatóan meg kell ismerni, s legfeljebb az államhatár egyes területekre gyakorolt hatásait írhatjuk le elméleti szinten. E regionális vizsgálatok a magyar tudományban a nyolcvanas években jelentek meg először, s úttörő jelleggel a Magyar Tudományos Akadémia Regionális Kutatások Központja végezte az első, átfogó ilyen irányú kutatásokat (Erdősi 1988; Rechnitzer 1990). A vizsgálati irányt az MTA RKK-n belül a Nyugat-magyarországi Tudományos Intézet a kilencvenes években következetesen magáénak tudta, s vizsgálta a 
határmentiség kérdését, elsősorban a nyugati (osztrák-magyar) határ térségében, $\mathrm{s}$ e vizsgálódások eredményeit két tanulmánykötet (Rechnitzer 1990; Nárai-Rechnitzer 1999), s számtalan tudományos publikáció foglalja össze. Az évtized végére a kutatások vizsgálati területe kibővült, $\mathrm{s}$ már a teljes ország határ menti területeinek kutatása, a magyarországi határtérségek általános problémái, az együttmüködések szervezése áll a kutatás középpontjában (Hardi 2000). A további vizsgálatok súlyponti kérdése a határ másik oldalának megismerése, a szomszédos országok határ menti térségeiben zajló folyamatok feltárása, a területi szereplők, az együttmüködésekben részt vevő (jelenlegi és lehetséges) partnerek viselkedésére ható, a magyarországitól eltérő szabályozások, szokások, lehetőségek, szándékok megismerése. Ez a fajta munka már nem egy kis intézet sajátja, hanem egy szélesebb összefogás eredménye. Az MTA RKK NYUTI vezetésével alakult ki az RKK-n belül egy informális csoport, egy hálózat az RKK különböző kutatóhelyein múködő kutatókból, amely választ keres a felmerült kérdésekre. Emellett a másik oldal vizsgálata igényli a határon átnyúló kapcsolati rendszer folyamatos erősítését a szomszédos országokban.

$\mathrm{Az}$ osztrák-magyar határ vizsgálata során a határtérségben zajló általános fejlödési folyamatok mellett az egyes speciális kérdések feltárása is napirendre került: az innováció terjedése a határtérségben (Rechnitzer 1990), a munkaeró és a demográfia speciális, az osztrák-magyar határtérségre vonatkozó elemei (Csapó 1999), a vállalkozók (Dóry 1999) és különösen a női vállalkozók (Szörényiné Kukorelli 1999) helyzete a határtérségben, a lakosság tudatában kialakult mentális határ vizsgálata (Hardi 1999; Izsák 1999; Nárai 1999).

Jelen tanulmány az intézeti kutatási eredmények szintéziseként azt kívánja bemutatni, hogy az elmúlt több mint egy évtized alatt milyen változások zajlottak le az osztrák-magyar határtérségben, hogyan változott meg a gazdaság és a társadalom helyzete, s hogyan alakultak ki és át a határon átnyúló együttmüködések, amelyek az osztrák-magyar határtérséget Magyarországon a határon átnyúló kapcsolatok mintaterületévé tették.

\section{A határ és a határtérség kialakulása}

$\mathrm{Az}$ osztrák-magyar határ, hasonlóan a többi határunkhoz fiatal államhatár, kialakulása az 1920. évi békerendszerhez kötődik. Több olyan sajátossággal rendelkezik azonban, amelyek a határ történetét elkülönítik a többi határunktól. Az első világháború után meghúzott határ két vesztes állam között jött létre, a békét megalkotó nagyhatalmaknak az osztrák-magyar határ esetében nem voltak olyan stratégiai céljaik, mint a többi szomszédos ország esetében. A Magyarországgal szembeni osztrák követelés Vas, Sopron és Moson megyére vonatkozott, amelyekből a végleges megállapodás csak $3600 \mathrm{~km}^{2}$ területet engedett át. A határ meghúzása közel állt a wilsoni elvekhez, mivel viszonylag kis számú magyar lakos maradt az osztrák oldalon, s mintegy az önrendelkezés tiszteletben tartásának 
bizonyítása érdekében az 1921. október 13-án kelt velencei jegyzőkönyv értelmében került sor Sopronban népszavazásra, annak eldöntésére, hogy melyik államhoz tartozzon a város. A decemberben tartott népszavazás Magyarország javára dölt el, $\mathrm{s}$ az elcsatolt területek 1922. január 1-jén kerültek osztrák közigazgatás alá. (A békét előkészítỏ hatalmak a stratégiailag fontosabb helyeken már nem voltak ennyire engedékenyek: Maribor és Klagenfurt lakossága a nemzetiségi megoszlás ellenére sem dönthetett önmaga a hovatartozásáról [Ormos 1997].)

A két világháború közötti időszakban az új határok a politikai viszonyoknak megfelelỏen erösen elválasztó jellegủek voltak. A szomszédos országok magyarország-ellenes politikája miatt az államhatárok megszakították a korábban létezỏ térségi kapcsolatokat, s elzárták egymástól a határ két oldalán élőket, legtöbbször olyan területeken, ahol a lakosságot szoros rokonsági, nemzetiségi kapcsolatok füzték össze, nem is beszélve az évszázadok során kialakult gazdasági és térségi kapcsolatokról. Az osztrák-magyar határ esetében az államhatár meghúzása nem hozott ennyire szigorú változást. A két ország között kölcsönös birtoklásról szóló egyezmény létezett egészen 1948-ig, így a korábbi birtokosok megtartották területeiket a határ másik oldalán, s átjártak dolgozni, termelni. A soknemzetiségú területen horvátok, magyarok és németek egyaránt kerültek a határ mindkét oldalára, s ök a kapcsolataikat fenntarthatták. A településhálózatban a városok fejlődését mindazonáltal megnehezítette, hogy a határ elvágta őket vonzáskörzetüktől, ez különösen Sopront, Mosonmagyaróvárt érintette, valamint Szombathelyt. Az elvágott megyerészekből összeálló Burgenland viszont jelentős városi központ nélkül maradt.

A határ igazi elválasztó szerepe a negyvenes évek végétől, az ötvenes évek elejétől bontakozott ki. A korábban könnyen átjárható osztrák-magyar határ ekkortól két világrend elválasztó gátjává lényegült át, melynek stratégiai jelentősége különös figyelmet váltott ki a mindenkori hatalom részéről. Ennek köszönhető, hogy az ötvenes években a jugoszláv határ mellett itt épült ki a híres „vasfüggöny”, melynek védelme müszaki zárból (aknamezőből, kerítésekből), s rendkívül szigorú határőrizetből, utazási korlátozásokból âllt össze. A taposóaknák egészen 1965-ig maradtak a helyükön, majd a magyar határörség kiépítette az elektromos kerítésekből álló jelzőrendszert, melynek lebontására 1989 nyarán került sor (Hardi 1999; Teke 1999; Sallai 2001). Magyarország többi, szocialista államokkal közös határa hasonlóan szigorúan elválasztó jellegú határ volt, azonban a szocialista államok közötti utazási lehetöségek lényegesen kevésbé voltak korlátozottak, mint az osztrák határ átlépése. Ebben a kérdésben változást igazán a „világútlevél” bevezetése hozott 1987-ben, aminek hatására korábban elképzelhetetlen tömeg indult útnak Ausztria felé (,gorenje-korszak”). Az 1989-1990. évi változások, illetve Ausztria EU belépésének következtében az osztrák-magyar határ és határtérség élete teljes egészében megváltozott. A gazdasági lehetőségek, majd a schengeni normák bevezetése következtében a hatalom figyelme ismét kitüntetetten irányult az osztrák-magyar határtérségre, de most már pozitív elöjellel. A 
szomszédos országokban bekövetkező események a többi határtérségre nézve alapvető problémákat jelentettek. Az egykori Jugoszlávia szétesésével járó háborúk, Románia, Ukrajna esetében az elszegényedés, a gazdaság erős hanyatlása, az erősödỏ román és szlovák nacionalizmus az évtized elején negatívan hatottak a többi határtérség fejlődésére, azokban több éves határzár (Baranya megye) vagy az erős kriminalizálódás (ukrán határ mente) bénította meg a fejlődést. Ezzel szemben a kilencvenes években az osztrák-magyar határtérség a békés fejlödés területe volt, ahol a csempészek (föleg embercsempészek) áramlási útvonalain és az illegális munkavállaláson és a zsebszerződéseken kívül inkább a gazdasági fejlődésröl, az együttmúködések bővüléséröl számolhatott be a média (Izsák 1999).

\section{Átalakuló térszerkezet}

A térség térszerkezetét alapvetỏen meghatározza a Kárpát-medence leginkább dinamikus és hagyományos közlekedési tengelyének, a Bécs-Budapest folyosónak a jelenléte. Ez a közlekedési tengely fejlett közúti, hagyományosan fejlett vasúti, valamint a Duna által folyóvízi összeköttetést jelent. A legfontosabb jellegzetessége, hogy a kommunikációs irányok a Dunával párhuzamosan futnak (ÉNY-DK-i irányúak), s gyengék az észak-déli irányú összeköttetések. Ez az irány jellemző a három centrum település (Bécs, Pozsony és Győr) egymás közötti kommunikációjára is, a kapcsolat döntö iránya a Györ-Bécs és a Pozsony-Bécs irány). Jelentős infrastruktúrával is elsősorban északnyugat-délkeleti irány rendelkezik. Autópálya/autóút összeköttetés, valamint nagy teljesítményü határátkelöhely található Hegyeshalomnál (H/A). Az észak-déli irány infrastrukturális kiépítettsége jelentős mértékben gyengébb. Ennek kiépítése várható, mivel az észak-déli összeköttetés alapvetöen fontos a Nyugat-dunántúli régió kohéziójának megteremtéséhez. Ráadásul egy ilyen irányú közúti és vasúti korridor fejlesztése osztrák érdek is, mivel Ausztriától vonhatná el a jelentős környezetszennyezéssel járó észak-déli nemzetközi tranzitforgalmat a Pozsonytól Szlovéniáig terjedő szakaszon.

Burgenland viszonylag kis területủ tartomány, területe $3966 \mathrm{~km}^{2}$, lakóinak száma (1996) 277500 fö. Voltaképpen a királyi Magyarország nyugati peremterületéböl alakult, az egykori Moson, Sopron és Vas megye töredékeiböl. Így földrajzilag több furcsasága is kialakult a tartománynak. Hosszú észak-déli kiterjedéséhez keskeny kelet-nyugati szélesség társul. Az utóbbi évtizedben épưlt közúti összeköttetések javítottak a helyzetén, de valójában közlekedési kapcsolatok nem biztosítják a tartomány kohézióját, mivel a valós, tradicionális kommunikációs irányok a Magyarországon maradt központi településekkel és az osztrák fövárossal kötötték össze a térséget.

Másrészt a terület a határmegvonás következtében jelentős térségi centrum nélkül maradt. Fontosabb települései a két egykori szabad királyi város, Kismarton (Eisenstadt) az Esterházy-birtok központja és Rohonc, valamint az egykori uradalmi központok, úm. Németújvár, Pinkafö. Igazi térségi centrumok Sopron, Kőszeg, 
Szombathely és Szentgotthárd voltak. A tartomány mai városai később fejlődtek ki községekböl (pl. Oberwart-Felsőőr). A legfontosabb centrumok továbbra is a tartományon kívüli Wiener Neustadt-Bécsújhely és Bécs maradtak még a délburgenlandi területek számára is (Kampschulte 1999; Baumgartner-Kovács-Vári 2001). Településhálózatára ma is jellemzö a viszonylag kis méretü települések sokasága. Eisenstadt kivételével minden település lélekszáma 10000 fỏ alatt van, míg a települések 65\%-a található az 500-1999 lakosú kategóriában.

$\mathrm{Az}$ államhatár ma már egyre kevésbé akadályozza a térszerkezeti vonalak összekapcsolódását. Napjainkban az osztrák határ több szempontból is hazánk legfejlettebb határának számít. Közlekedési szempontból lényeges, hogy egyetlen olyan határunk, ahova autópálya és fejlett vasúti pálya (kétvágányos, $160 \mathrm{~km} / \mathrm{h}$ sebességre alkalmas) vezet. A határátkelők sürüsége megfelelő. Bár schengeni határ, de az utasforgalom várakozási ideje, az átlépés kulturáltsága lényegesen jobb, mint keleti határainkon. Az osztrák fél sem támaszt hivatalos vagy informális akadályokat a határátlépéssel szemben (ellentétben a keleti határokon megszokott kulönbözö „illetékekkel”, baksisokkal stb.).

A határátkelốk közül Magyarország egyik legnagyobb forgalmú, közúti és vasúti viszonylattal is rendelkező határátkelőhelye Hegyeshalom. Itt az átlépők száma éves viszonylatban 10 millió fő felett van. Hasonló nagyságrendet ér el Sopron, ahol az átlépỏk száma meghaladja az évi 8 millió fơt, valamint Rábafüzes (vasúti és közúti viszonylat is). Ezeken a határátkelőkön a magyar és osztrák átlépők aránya 50\% alatt marad, hiszen ezek az irányok a nagy nemzetközi útvonalak irányába esnek, $\mathrm{s}$ elsősorban tranzit forgalom lebonyolítását végzik. A kisebb határátkelöket, úm. Kópháza, Bucsu elsösorban magyar és osztrák állampolgárok használják, míg a legkisebbek, Fertőd, Bozsok, Szentpéterfa, Fertőrákos a térségi igények kiszolgálására létesültek, általában csak magyar és osztrák állampolgárok használhatják őket, $\mathrm{s}$ több közülük korlátozott nyitvatartással üzemel. Az ideiglenes határnyitások (pl. Zsira, Várbalog térségében) pedig kimondottan helyi igényekre épülnek, az egyes telepullések vezetői kérésére nyílnak meg egy-egy alkalomra, a falvak búcsúi vagy más ünnepei alkalmából.

\section{Átalakuló társadalom}

Az 1990 elötti évtizedekben a határ zártsága kimondottan hátrányosan érintette a határ menti területek fejlődését. Ez elsősorban az osztrák-magyar határra értendỏ, de az ötvenes években hasonlóképpen korlátozták a jugoszláv-magyar határ menti fejlesztéseket is ideológiai okok miatt (Tito kiközösítése a szovjet érdekszférán belül). Az osztrák-magyar határtérség szándékosan fenntartott periférikus helyzete egészen a nyolcvanas évek közepéig-végéig fennállt. Ez beruházási korlátozásokat jelentett, ami infrastrukturális és gazdasági hátrányokat egyaránt okozott, másrészt a helyben élő és idelátogató lakosság mozgását gátló és ellenörző intézkedéseket. 
Ennek a helyzetnek (is) köszönhető, hogy a térségböl jelentőssé vált az elvándorlás, s romlott a demográfiai helyzet (Csapó 1999).

A világútlevél bevezetésével és a rendszerváltással a határ már nem jelentett akadályt a lakossági napi kapcsolatok elött, s a gazdasági lehetöségekben is lényeges javulást hozott. A lakossági kapcsolatok gyors élénkülését jelzi, hogy ebben a térségben váltották ki a lakosok a legnagyobb arányban a világútlevelet 1989-ig. A mosonmagyaróvári, soproni, kőszegi városkörnyékben 1000 före a 650 db-ot (65\%) meghaladta a kiadott útlevelek száma, de a többi térségben is magas volt, a legtöbb helyen 50\% feletti volt ez az arány (Rechnitzer 1999b). Vizsgálataink ${ }^{1}$ szerint a lakosság $66 \%$-ának van valamilyen kapcsolata az osztrák oldalon, s a kapcsolatok 60\%-a szövődött 1989 után (Nárai 1999) (1. ábra).

\section{1. ÁBRA}

A szomszédos országba irányuló lakossági kapcsolatok létrejöttének idöbelisége (\%) (People's Relationships to the Neighbour Country from the View of Their Originating)

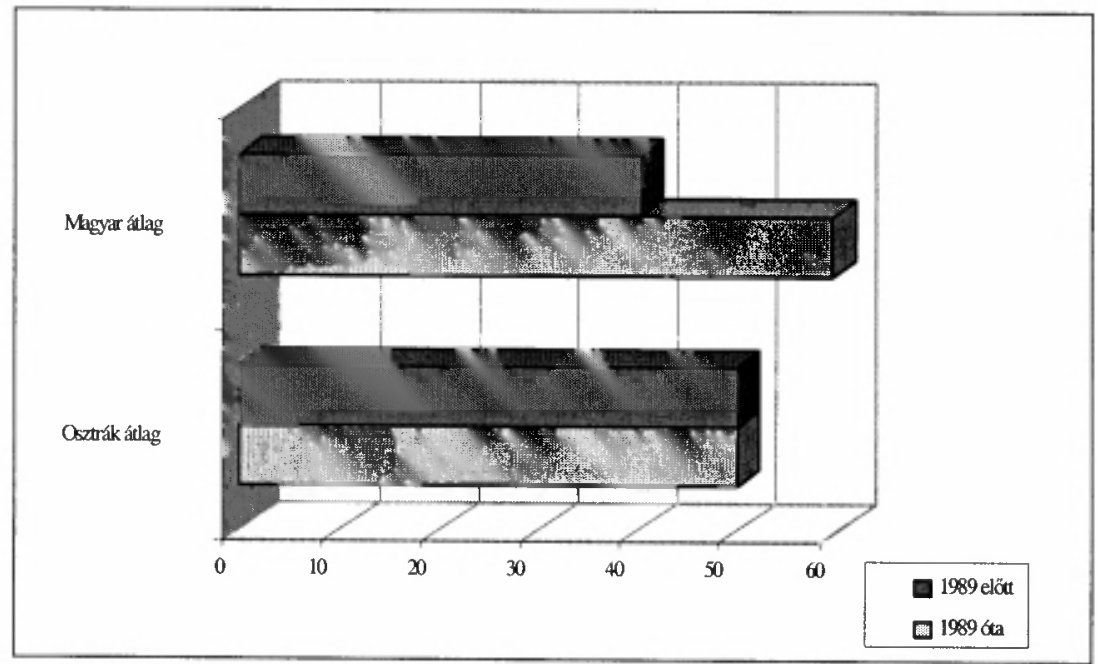

Forrás: Kérdőívek 1998.

1989 elött az utazási korlátozások ugyan a magyar lakosság kiutazását alacsony szinten tartották, de az Ausztriából érkező turisták révén léteztek kapcsolatok a lakosok között is. Az 1989. évi változások, ill. korábban a világútlevél bevezetése robbanásszerủ növekedést okozott az utazások számának növekedésében magyar részröl, így a kapcsolatok többsége is ez után a dátum után keletkezett. A kapcsolatok relatíve magas aránya rávilágít arra, hogy az emberek fejében a szomszédos országról, „világról” alkotott kép ma már elsősorban személyes tapasztalatokon alapul.

A magyarországi megkérdezettek körében az ausztriai kapcsolattal rendelkezők aránya az iskolai végzettség emelkedésével növekszik (míg arányuk a kevesebb, mint nyolc osztályt végzettek körében 19\%, addig a diplomások körében már 73\%). 
Igazi nagy ugrás az elöbb említett csoport és az általános iskolát végzettek között van, ez utóbbiak 59,6\%-a bír valamilyen kontaktussal. Az életkort tekintve a legfiatalabb (20 év alattiak) és a legidősebb (60 év felettiek) korosztályba tartozó megkérdezettek körében tapasztaltuk a legalacsonyabb arányokat (50\% körüli értékek), a többi korcsoport esetében $70 \%$ körüli a kapcsolattal rendelkezök aránya. A gazdasági aktivitással összevetve a vizsgált változót, azt az érdekes megállapítást tehetjük, hogy a legmagasabb, és a többi csoporthoz (nem önálló, tanuló, nyugdíjas, háztartásbeli, munkanélküli) képest jelentősen magasabb az önállók körében a kapcsolattal nem rendelkezök aránya (81\%, szemben a többi csoport $27 \%-40 \%$ közötti értékeivel). A burgenlandi megkérdezettek körében a diplomások és az érettségizettek körében a leggyakoribb a magyarországi kapcsolat (84\% ill. 71\%), az életkor tekintetében legalacsonyabb a 20 évnél fiatalabbak körében (54\%), az összes többi korcsoportnál ez az érték több mint $60 \%$.

A baráti, rokoni kapcsolatok sem ritkák, elsősorban a határ mindkét oldalán élő nemzetiségek (magyarok, németek, szlovénok, horvátok) révén, de a kapcsolatok egy jelentơss részét a gazdasági tényezők határozzák meg (bevásárlás, munkavégzés, ưzleti utazások) (2. ábra). A hazánkba látogató burgenlandiak jelentös része elsősorban perszonális kapcsolatai miatt, illetve rekreációs céllal, pihenni, szabadságát eltölteni utazik Magyarországra. A vásárlási célzatú utazások előfordulása is gyakori, de felmérésünk szerint annak ellenére, hogy hazánkat elsősorban az olcsóbb vásárlási lehetőségekkel társítják, a tényleges kapcsolatok szintjén azonban az ilyen célú utazások „csupán” a harmadik helyen szerepelnek.

\section{2. ÁBRA}

A szomszédos országba irányuló lakossági kapcsolatok jellege (\%)

(Characteristic of People's Relationships to the Neighbour Country)

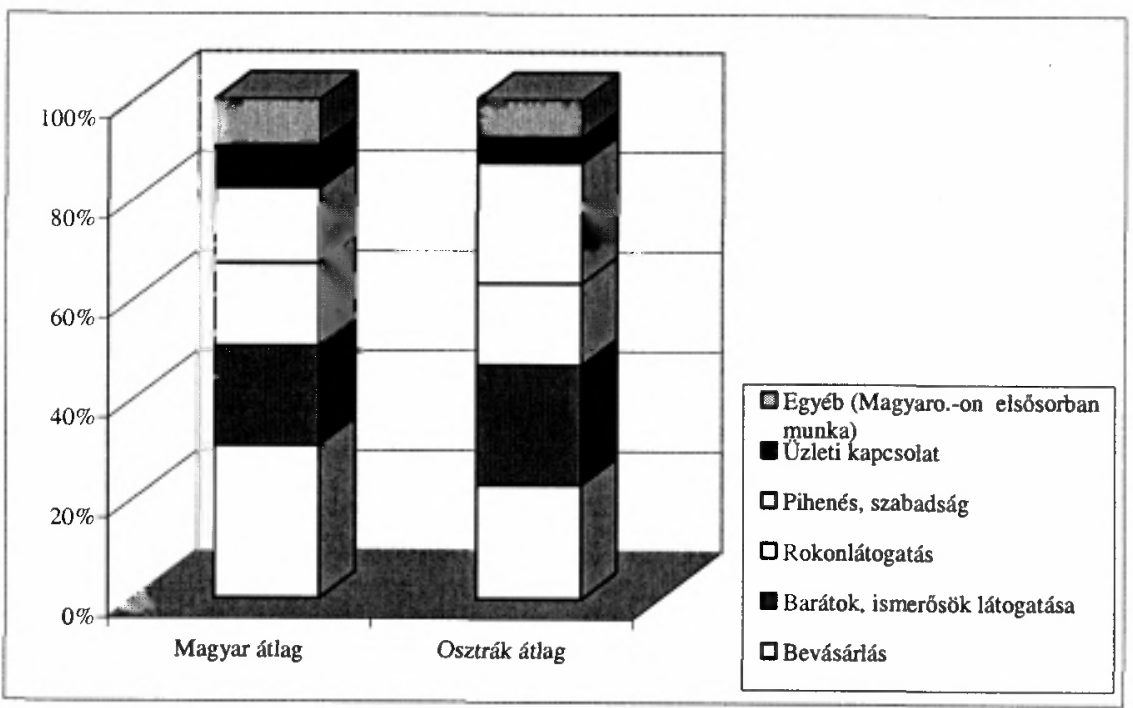

Forrás: Kérdőívek 1998. 
A bevásárló-turizmus a lakosság legszélesebb rétegeit érintette a kilencvenes évek elején. Egyrészt a saját bevásárlások révén, másrészt az ország belsejéböl érkezó „kereskedők” számára biztosítottak tárolási lehetőséget, harmadrészt a magyar árukínálat bóvülésével, a piacgazdaság, így a színvonalas szolgáltatások, kereskedelem kialakulásával az osztrákok részéröl megnyilvánuló, vásárlási, szolgáltatás-igénybevételi szándékú beutazások száma is megnövekedett. Azóta ennek intenzitása magyar részről csökkent, mivel a korábban Ausztriában vásárolt termékek már Magyarországon is kaphatók, s az árkülönbözet is eltünt. Az osztrák oldalról változatlanul érkeznek a bevásárlók, bár ritkábban, mint az évtized elején, hiszen az árkülönbségek csökkenése az általuk preferált cikkeknél szintén csökkent. A bevásárlások szerkezete átalakult. Egyrészt inkább a nagybevásárlások szerepe nőtt meg, másrészt a szolgáltatások igénybevétele vált döntővé (orvosi ellátás, éttermi étkezés, lakodalmak rendezése, fürdők használata). A vásárlási célzatú kiutazások elsősorban a nökre jellemzők, üzleti kapcsolattal inkább a férfiak rendelkeznek. Az iskolai végzettség emelkedésével csökken (a kevesebb, mint nyolc osztályt végzettek kétharmada, a diplomások $36 \%$-a), az életkor emelkedésével pedig nó (a 20 év alattiak ötöde, míg a 60 évesnél idösebbek kétötöde) a rokoni, baráti, ismerösi kapcsolattal rendelkezők aránya. A vásárlás, illetve az üzleti jelleg elsősorban a legfiatalabbak kontaktusait jellemzi, a kvalifikációs szint emelkedésével pedig fokozatosan nő azok aránya, akik rekreációs célzattal utaznak a szomszédos országba. Az ausztriai megkérdezettek körében a rokoni kapcsolatok inkább a nőkre és középkorúakra, az üzleti jellegü viszonyok elsősorban hasonlóan a magyarországi eredményekhez - a férfiakra, illetve a magasan képzettekre jellemzö (az alapfokú végzettségüek körében 3,3\%, az egyetemi diplomával rendelkezők körében már 22\%). A 30 évesnél fiatalabbak döntően vásárolni, az idősebb korosztályok (50 év felettiek) pedig pihenni, nyaralni, barátokat látogatni járnak át Magyarországra. Az eredmények tehát azt mutatják, hogy a bemutatni kívánt határrégió lakosságának szomszédos országba irányuló kapcsolatai nemcsak a fogyasztásra, vásárlásra korlátozódik, hanem jelentős részben perszonális, személyek közötti közvetlen interakciókat jelent.

A kapcsolatokat azonban nem igazán intenzív viszony jellemzi. A lakossági átjárás gyakoriságának, intenzitásának alakulását a 3. ábra mutatja.

A határ magyar oldalán élők tizedének nincs semmiféle kapcsolata a túloldalon lévő közeli településekkel, azok lakosságával. Ök legnagyobb arányban a legfiatalabb és a legidösebb, illetve az alacsonyan képzettek közül kerülnek ki. A heti vagy napi rendszerességủ kapcsolatok elsősorban a fiatalokra jellemzőek. Felmérésünk szerint az osztrák oldalról a nagyobb aktivitás a férfiakra jellemzö, viszont a megkérdezettek ötöde még soha nem járt a határ magyar oldalán lévö közeli településen. 


\section{3. ÁBRA}

A határon túli szomszédos településre irányuló lakossági kapcsolatok intenzitása (\%) (Intensity of People's Relationships to the Neighbour Settlement of the Other Side of the Border)

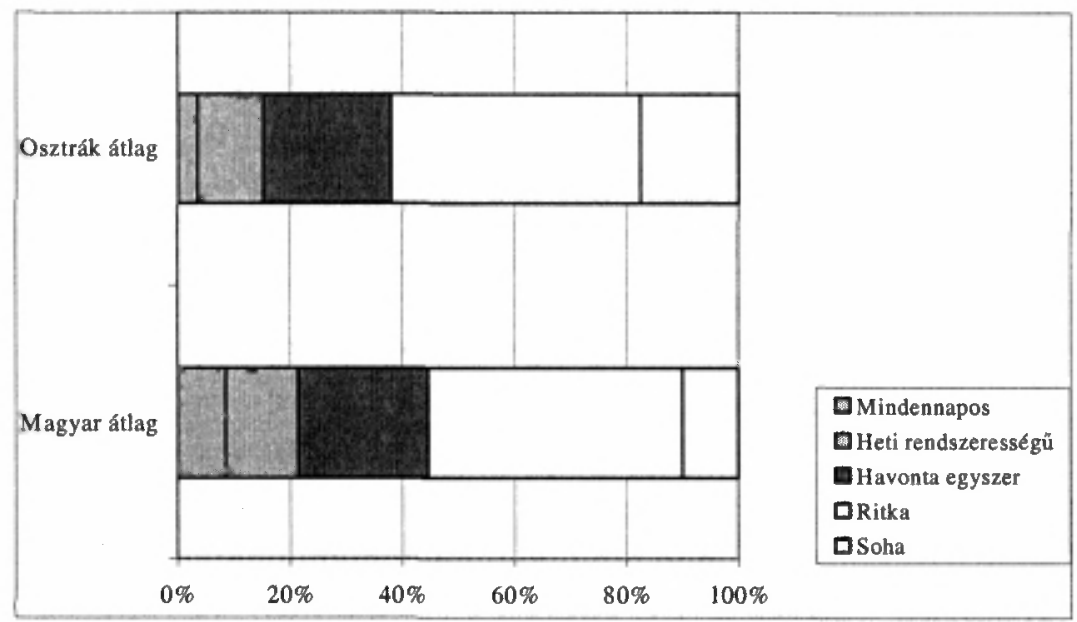

Forrás: Kérdöívek 1998.

Magyar részról fontos kiutazási céllá vált a munkavállalás. Ez részben hivatalos, részben illegális formában valósul meg. A hivatalos munkavállalások számát egyezmény határozza meg. A két határ menti megyében állandó lakhellyel rendelkező magyar állampolgárok számára évente meghatározott kontingensig van lehetóség a munkavállalásra Ausztriában. Lényegében legalizâlták az eddigi folyamatokat, továbbá 300 fơre gyakornoki munkavállalást (18-30 év között) biztosítottak, s végúl 19 szakmát kölcsönösen elismertek, ami a munkavállalás körülményeit kedvezöbbé tette (Rechnitzer 1999b). A Nyugat-dunántúli régió három megyéjéból jelenleg (2000 októbere) 900 fớ részére biztosítanak munkavállalási lehetőséget az osztrák hatóságok. Ennek a keretnek a 2/3-át GyórMoson-Sopron megyei munkavállalók használják, míg a maradék egyharmadot Vas és Zala megyeiek.

A munkavállalás másik formája az illegális munkavállalók köre, akik számára csak nagyon durva becsléseket alkalmazhatunk. Interjú formájában megkérdeztük az egyes határör kirendeltségeket, hogy mennyire becsülik a naponta, munkavállalási céllal kilépỏ magyar állampolgárok számát. A bizonyos napszakokban kilépó, ill. belépó utazókról nagy biztonsággal lehet sejteni, hogy munkavállalási céllal távoztak külföldre. Mindezek alapján 5000 és 7000 fó kỏzé tehetó a naponta ingázók száma Győr-Moson-Sopron megyében. A teljes osztrák határszakaszon ez a szám 10-15 000 fỏ lehet. Az ellenörzött burgenlandi munkaadók 30-44\%-a illegálisan alkalmazott külföldit. A legális munkavállalók esetében az osztrák fél elégedetlenségét az okozza, hogy a magyarországi ingázók tartózkodási engedély nélkül is vállalhatnak munkát, s ez leszorítja a béreket. A legálisan kiadható 
engedélyek számát a munkaügyi hivatalok települések szintjére lebontva korlátozzák, ez viszont ismét csak az illegális munkavállalás felé löki a szereplöket. Másfelól azonban a burgenlandi gazdák nagyobb része nem kizárólag a földből, hanem a bécsi munkahelyéböl él, s ez a családi munkamegosztás rendszerére is kihat. A probléma súlyát jelzi, hogy például az osztrák szakszervezetek Sopronban és Szombathelyen tanácsadó-irodát állitottak fel, hogy az Ausztriában munkavállaló magyarok megismerkedjenek a legfontosabb munkavállalói jogokkal, illetve megtudják azt, hogy kihez fordulhatnak jogaik megsértése esetén.

Munkavégzés céljából osztrák oldalról is egyre többen jönnek Magyarországra. Egyrészt a határ menti ipari területek, elsősorban a Szentgotthárdi Ipari Park területén lévő vegyes tulajdonú üzemek vezető beosztású dolgozói, másrészt, a magyarországi földeket bérlö, ill. tulajdonló osztrák parasztok járnak át ebból a célból.

A közös munkaügyi problémák megoldására osztrák és magyar szakemberek munkájával készült el 1998-ban Nyugat-Magyarország (Györ-Moson-Sopron, Vas, Zala megyék) és Kelet-Ausztria (Burgenland és Steiermark tartományok) közös munkaerö-piaci stratégiája.

A lakossági kapcsolatok kategóriájába sorolandó az osztrák állampolgárok ingatlan-szerzése a térségben. A külfö̀ldiek földtulajdon szerzése szorosan kötődik a kárpótlásokhoz. Néhány külföldi tulajdonos ugyan alanyi jogon jutott így földterülethez (az összes kárpótolt 3-5\%-a), de a kárpótlási jegyek felvásárlásánál, licitálásoknál gyakran fedezhető fel az ausztriai érdekeltség. Becslések szerint a két megye szántóföld teruleteinek 10-15\%-a lehet kapcsolatban osztrák bérlökkel (Rechnitzer 1999b).

A gazdasági élénkülés, a munkalehetőségek jelentős előnyöket rejtenek a nyugati határszélen a lakosság számára. Kérdőívben kérdeztük meg a határ mentén élőket, hogy milyen előnyöket jelent a határ menti élet. A legtöbb válaszadó Ausztria közelségét, a könnyü határátlépést nevezte meg elsősorban, majd rögtön utána a munkavállalási és gazdasági előnyöket. Igaz, a szabadságért cserébe elvesztek az 1989 elött tapasztalható elönyök: a szigorú határórizet szinte teljes mértékben kisöpörte a kriminalitást a mindennapokból, a határ menti falvakban felesleges volt kulcsra zárni az ajtókat. A kinyíló határ a devizagazdálkodás kötöttségei ellenére is mágnesként vonzotta a másik oldalt megismerni vágyókat, a bevásárló útra indulókat, de velük együtt megjelent a feketekereskedelem, majd a csempészet (embercsempészet) is. A forgalom kezdeti növekedésére jellemzö, hogy 1988-ban 5 millió látogató érkezett Ausztriába hazánkból, 1989-ben már 9,4 millió fö (Rechnitzer 1999b) - mintha egész Magyarország elindult volna nyugatra. Ez a jelenség nagy terheket rótt a határ mentén élökre, de egyben fontos gazdasági lehetőségeket is jelentett. Az ország más területeiről érkező kereskedők számára sokan kiadták a garázsaikat, helyiségeiket amolyan „depó” céljaira. A bevásárlóturizmus hihetetlen felfutásának alapja a müszaki cikkek árkülönbözete, s a nyugati életforma addig nálunk csak drágán és ritkán kapható, néha kétes minőségü árui utáni vágyakozás volt, valamint - valljuk be - az a tény, hogy sokan ekkoriban 
mehettek (legalábbis megkötések nélkül) nyugatra, s ez a lehetőség egy új világba való belépés érzetét is keltette. Mindezek az alapok természetesen elég ingatagok voltak ahhoz, hogy a határtérség gazdasági fejlödését hosszú távon megalapozzák, ráadásul földrajzi értelemben a határátkelök környékére koncentrálódtak, a határátkelőktöl távolabb elhelyezkedő települések ezekből vajmi keveset éreztek meg.

Így nem csoda, hogy a korábban elvándorlással sújtott területek a kilencvenes években vándorlási nyereséget könyvelhettek el, néhány kivétellel, de a negatív elöjelü eredmények is inkább a stagnáló vándorlási különbséget mutatják (1. táblázat).

\section{TÁBLÁZAT}

Vándorlási különbözet az osztrák határ menti kistérségekben 1995-1998 között

(Net Migration of the Small Regions in the Austrian Border Land between 1995 and 1998)

\begin{tabular}{cc}
\hline KISTÉRSÉG & $\begin{array}{c}\text { Vándorlási különbözet 1995-1998 között } \\
\text { ezrelék }\end{array}$ \\
\hline Csorna & $-4,0$ \\
Györ* & 15,3 \\
Kapuvár & $-7,9$ \\
Mosonmagyaróvár & $-3,9$ \\
Sopron & 13,9 \\
Csepreg* & 6,3 \\
Körmend & $-5,7$ \\
Köszeg & 48,6 \\
Szentgotthárd & 23,3 \\
Szombathely & $-1,8$ \\
\hline
\end{tabular}

*= A győri és csepregi kistérség ugyan nem határos Ausztriával, de funkcionális kapcsolatai miatt az osztrák-magyar határtérség vizsgálata esetén érdemes bevonni az elemzésbe.

Forrás: KSH Tstar alapján saját számítás.

\section{Az átalakuló gazdaság}

A gazdaság jelenlegi határokat átívelö összekötöttsége történelmi múltra tekint vissza a térségben (Rechnitzer 1997; 1999a; 1999b; 1999c). Bécs élelmiszerszállító hátországát jelentette a terület évszázadokon át. Győr szerepe a magyar gabona nyugat felé történö forgalmazása kapcsán közvetlenuil kötődött Bécshez, elöször vízi úton, majd 1855-től a gabonaszállítás céljából kiépülő Bécs-Győr vasúton (Sári 2001). A határok megvonásával (1920 és 1922), valamint a vasfüggöny létrejöttével (1948) ezek a gazdasági kapcsolatok megszakadtak. A gazdaság fejlödése szempontjából a térség helyzete alapvetóen megváltozott a kilencvenes évtizedben. $\mathrm{Az}$ osztrák határ menti megyék a nyugati tőke fogadóállomásává váltak (Budapest mellett), a korábban elzárt határ menti területek értéke nagymértékben megnőtt. Ehhez hozzájárult a földrajzi közelség, a hosszú múltra visszatekintő kapcsolatok, a 
hagyományos munkakultúra, s nem utolsó sorban a kiépuilö, jó minőségü közlekedési infrastruktúra (Bécs-Budapest tengely). Ennek eredményeképpen GyörMoson-Sopron és Vas megye tökevonzó képessége országos viszonylatban kiemelkedő. Az egy lakosra jutó befektetett külföldi töke 1999-ben Budapest után $(798700 \mathrm{Ft}$ ) Györ-Moson-Sopron megyében volt a legmagasabb az országban $(367800 \mathrm{Ft})$, Vas megye Györ-Moson-Sopron és Pest $(232600 \mathrm{Ft})$ után a harmadik helyet érte el (223 600 Ft) (az országos átlag $254400 \mathrm{Ft}$ ). A többi megyék lényegesen lemaradva követik az elsöket.

A cégalapítási aktivitás tekintetében a szomszéd országok közül Ausztria jár az élen. Györ-Moson-Sopron megyében Ausztria a második legnagyobb müködőtóke befektető, jelentősek a kis- és középméretü Burgenlandból és Bécsböl származó vállalkozások. Hasonlóképpen az osztrák kapcsolatot jelzi a PHARE segítséggel 2000-ben befejezett győri Kereskedelmi Központ (Trade Center), amely a schwechati World Trade Centerrel együttmüködésben épült meg, valamint az osztrák tőkével és PHARE segítséggel kiépülő kikötő Gönyün².

2001 januárjában 4231 osztrák részvétellel müködö cég volt az országban, ennek mintegy a fele Budapesten. Jelentős a részvétel a határ menti városok gazdaságában. Szinte minden jelentősebb központban nagy számban vannak jelen az osztrák tulajdonú cégek, elsösorban Györben (105 db), Sopronban (162 db), Szombathelyen (112 db), Mosonmagyaróváron (72 db), Szentgotthárdon (31 db), de megtalálhatók a kisebb, de fontos településeken is (Bük, Fertöd, Köszeg).

A beruházások következtében a foglalkozási szerkezet jelentősen átalakult, $\mathrm{s}$ ez az átalakulás némileg eltér a magyarországi átlagtól. Míg egész Magyarország viszonylatában 1987 és 1999 között a mezögazdasági és az ipari foglalkoztatás jelentös visszaesése tapasztalható, addig térségünkben ez csak a mezőgazdaságra igaz (2. táblázat). Itt megmaradt, illetve újraépült az ipari ágazat dominanciája, $\mathrm{s}$ ez kiegészült a tercier szektor erősödésével.

\section{TÁBLÁZAT}

A foglalkoztatottság változása 1987 és 1999 között

(Change in Employment between 1987 and 1999)

\begin{tabular}{|c|c|c|c|c|c|c|c|c|}
\hline & \multicolumn{2}{|c|}{ Mezőgazdaság } & \multicolumn{2}{|c|}{ Ipar } & \multicolumn{2}{|c|}{ Építőipar } & \multicolumn{2}{|c|}{$\begin{array}{c}\text { Kereskedelem, } \\
\text { közlekedés és } \\
\text { szolgáltatás }\end{array}$} \\
\hline & 1987 & 1999 & 1987 & 1999 & 1987 & 1999 & 1987 & 1999 \\
\hline $\begin{array}{l}\text { Györ-Moson- } \\
\text { Sopron }\end{array}$ & 20,8 & 6,1 & 48,8 & 45,2 & 9,1 & 4,1 & 21,3 & 44,6 \\
\hline Vas & 25,3 & 7,3 & 40,2 & 49,5 & 5,4 & 4,0 & 29,1 & 39,2 \\
\hline Magyarország & 22,2 & 5,4 & 41,8 & 31,0 & 8,4 & 4,0 & 27,6 & 59,7 \\
\hline
\end{tabular}

Forrás: Rechnitzer (1990) és KSH Területi Statisztikai Évkönyv (1999) alapján.

A kilencvenes évek végére Magyarországon a határ menti területek fejlettségét a kistérségek szintjén ábrázolva megállapíthatjuk, hogy egybefüggỏ fejlett térségek határaink mentén csak a nyugat-szlovák és az osztrák határ mentén alakultak ki, míg 
máshol a határ menti fejlődés egy-egy város kedvezó pozíciójához kapcsolódik (Pécs, Szeged, Debrecen).

\section{A szomszédság: Burgenland}

Ausztrián belül Burgenland a legkevésbé fejlett tartomány, ugyanakkor azt is lehet róla mondani, hogy fejlődési dinamikáját tekintve első az osztrák tartományok sorában. Az egy lakosra jutó GDP csupán az országos átlag 64,6\%-a. A fỏ ágazatok közül a mezőgazdaság részesedése a megtermelt értékből és foglalkoztatottakból a legmagasabb az országban. A tartomány GDP-jéböl 3\%-kal, a foglalkoztatottakból 7,9\%-kal részesedik a primer szektor. Az ipar aránya viszonylag alacsony (a tartományi GDP-böl 31,8\%, a foglalkoztatottakból 34,8\% a részesedése 1997-ben). Így magas marad a szolgáltatások aránya (a GDP-ből $65,1 \%$-kal, míg a foglalkoztatottakból 57,4\%-kal részesedik). Általában elmondható, hogy a tartomány északi része fejlettebb, a hagyományosan fejlett mezőgazdaságának (korábban jellemző modern módszerekkel dolgozó nagybirtokok, jelenleg az adaptív mezőgazdaság - borászat - [Baumgartner-Kovács-Vári 2001]), valamint az egyre jelentösebb turizmusnak és a föváros közelségének köszönhetően.

Országos szinten a legmagasabb a munkanélküliségi ráta Burgenland tartományban, 9\% volt 1998-ban (az országos átlag ekkor 7,5\%), 1999-re némileg csökkenö értéket mutat. Ebbỏl a szempontból lényegesen rosszabb a helyzet, mint a szomszédos Györ-Moson-Sopron (4,4\%), Vas $(5,2 \%)$ és Zala $(8,0 \%)$ megyékben. A vállalkozások száma az osztrák oldalon lényegesen alacsonyabb, az ezer lakosra jutó vállalkozások száma 1998-ban Burgenlandban meghaladta a 30-at, míg ugyanez a mutató Györ-Moson-Sopron megyében 81 , Zalában 79 , Vas megyében 64 volt ebben az évben.

Bár Burgenlandot a legkevésbé fejlett osztrák tartományként vehetjük számba, ugyanakkor Ausztria legdinamikusabban fejlődỏ tartománya is. Az elmúlt tíz év során a tartomány gazdasági szerkezetének átalakítása nagyobb ívü volt, mint az országos átlag, elsősorban a mezőgazdaság arányának jelentős csökkenése miatt, szemben a másik két ágazat arányának növekedésével. Másrészt az országban Burgenland Alsó-Ausztria (Niederösterreich) után a legmagasabb GDP növekedést tudta elérni 1987 és 1997 között (3. táblázat).

A bruttó beruházások növekedése 1995-97 között a tartományok közül Burgenlandban volt a legmagasabb, $117 \%$-ot tett ki. A növekedésben jelentös szerepe van a szolgáltató, azon belül is a turisztikai ágazatnak. Mint a fenti arányokból kitünik, ha összehasonlítjuk a szolgáltató ágazat részesedését a foglalkoztatottakból és a megtermelt értékből, látható, hogy jobb a hatékonysága, mint a másik két ágazatnak. A turisztikai ágazat fejlödését mutató indikátorok a legjobbak az országban. A 100 lakosra jutó vendégéjszakák számának növekedése pl. 1998-99-ben 6,5\%-os volt, ami meglehetősen nagy számnak számít, az ágykihasználtság (23,2\% 1999-ben, az országos átlag $25,2 \%$ ) is 3,1\%-kal javult 1998-hoz képest. 


\section{TÁBLÁZAT}

A föbb ipari ágazatok aránya a megtermelt tartományi GDP-böl Ausztriában tartományonként, 1987-ben és 1997-ben

(Share of Main Industries from GDP in Austria by Lands in 1987 and 1997)

\begin{tabular}{lccccccc}
\hline \multirow{2}{*}{ Tartomány } & \multirow{2}{*}{$\begin{array}{c}\text { A tartományi } \\
\text { GDP változása }\end{array}$} & \multicolumn{5}{c}{ A mezögazdaság } & \multicolumn{3}{c}{ Az ipar } & \multicolumn{1}{c}{ A szolgáltatás } \\
\cline { 3 - 8 } & $1987 / 97(\%)$ & 1987 & 1997 & 1987 & 1997 & 1987 & 1997 \\
\hline Burgenland & 169,3 & 11,5 & 3,0 & 27,3 & 31,8 & 61,3 & 65,1 \\
Kärnten & 159,2 & 4,6 & 2,0 & 33,1 & 33,7 & 62,4 & 64,4 \\
Niederösterreich & 169,7 & 6,9 & 2,6 & 41,0 & 38,0 & 52,1 & 59,4 \\
Oberösterreich & 155,5 & 4,3 & 1,9 & 45,2 & 42,0 & 50,5 & 56,2 \\
Salzburg & 163,0 & 2,1 & 0,9 & 27,6 & 27,6 & 70,4 & 71,4 \\
Steiermark & 165,3 & 4,7 & 2,6 & 37,1 & 38,3 & 58,3 & 59,1 \\
Tirol & 157,4 & 2,2 & 1,2 & 32,1 & 30,3 & 65,7 & 68,5 \\
Vorarlberg & 159,6 & 1,2 & 0,8 & 42,7 & 40,1 & 56,0 & 59,1 \\
Wien & 160,8 & 0,2 & 0,1 & 24,2 & 21,6 & 75,5 & 78,3 \\
\hline Ausztria & 161,8 & 3,3 & 1,4 & 34,0 & 32,3 & 62,7 & 66,3 \\
\hline
\end{tabular}

Forrás: ÖSTAT.

Mint látható, az osztrák-magyar határ mentén két olyan terület találkozik, melyek gazdaságában eltérö hangsúlyokat találunk: Györ-Moson-Sopron és Vas megyében a fejlődés hordozója (jelenleg) elsősorban az ipar, míg Burgenlandban továbbra is a fejlett agrărium és a turizmus. Minkét oldal megegyezik abban, hogy országaik legdinamikusabb térségei, $s$ a közös fejlődésnek ez a dinamizmus lehet az alapvető záloga.

\section{Az összekapcsolódó gazdasági-társadalmi tér: az együttmüködések}

Az együttműködéseknek nagy lendületet adtak a határ két oldalán található régiók. A két régió közül a magyar oldal (Nyugat-dunántúli régió) az ország fejlett térsége, országos szinten jónak mondható infrastruktúrával, fejlett ipari, polgári múlttal, élénk gazdasági-társadalmi kapcsolatokkal. Osztrák oldalon Burgenland az ország talán legkevésbé fejlett régiója, jelentős városi központ nélkül, gyenge regionális kohézióval. Ami viszont mindkét régióban azonos, az a dinamika jelenléte. NyugatMagyarországon ez a dinamika a rendszerváltás utáni struktúraváltást, az országon belüli fejlődést jelentette, ami az általános gazdasági válság közepette jelentett egy új utat, Burgenlandban pedig Ausztria fejlettségi mutatóihoz való felzárkózást. Így a közös tér északi része egy dinamikus, urbánus, ipari fejlődés színtere, míg a déli területek belsö periférikus jellegzetességeiböl való kiszakadást segíti elö az együttmüködések hálózata. Mindenesetre a dinamikus régiók kapcsolat-kialakító késztetése lényegesen nagyobb, mint a periférikus, leszakadó régióké, így Magyar- 
országon ebben a térségben valósulhat meg az első, valóban „határon átnyúló régió", amelynek kommunikációs irányait nem uralják teljes mértékben a nemzeti centrumok. Ebben természetesen nagy segítséget nyújt az EU csatlakozás is.

A Magyarországon bekövetkezett kedvező politikai változásokkal, a határnyitással megszủntek a települések, térségek közötti együttmüködéseket akadályozó tényezők is.

A két oldalú kapcsolatok kezdeményezése, ápolása a települési önkormányzatok, intézmények, civil szervezetek szintjére került, ez az a terep, ahol a kooperációk széles, változatos köre kialakulhat (Kovács-Váradi 1996).

A határ menti települések szinte mindegyike rendelkezik határon átnyúló kapcsolattal, melyek elsősorban kulturális együttmüködések, de van példa gazdasági, illetve infrastrukturális kapcsolatokra is (pl. Szentgotthárd-Heiligenkreuz Ipari Park; Szentgotthárd-Jennersdorf szennyvíztisztítási megállapodás stb.). A települési szintủ kooperációk elsősorban hivatalos jellegủek, azok a lakosság felé általában csak kulturális vagy sport rendezvények formájában jelennek meg.

A települések sajátosságai, már mủködö kapcsolatai nagymértékben meghatározzák azt, hogy a lakosság milyen területen tart lehetségesnek határon átnyúló kooperációkat. Felmérésünk szerint a magyar határ menti lakosság jelentős része kulturális és sport jellegü együttmüködésben gondolkodik, különböző közös rendezvények, cserekapcsolatok szervezését emelték ki. Hasonlóan magas azok aránya is, akik a gazdaság területén látnak együttmüködési lehetöségeket (pl. határon átnyúló ipari park, közös vállalatok, illetve munkaerö, szellemi töke kihasználása), ök legmagasabb arányban az önáló foglalkozásúak és a legfiatalabbak közül kerülnek ki.

A határtérség ausztriai oldalán élök elsósorban gazdasági, másodsorban kulturális területen képzelnek el határon átnyúló együttmüködéseket, de hangsúlyos az idegenforgalmat és az infrastrukturális fejlesztéseket említók aránya is (4. táblázat).

\section{TÁBLÁZAT}

Egy osztrák-magyar határ menti együttmüködés lehetséges területei a lakosság véleménye szerint (\%)

(Probable Areas of an Austrian-Hungarian Cross-Border Co-operation by the Opinion of People)

\begin{tabular}{lcc}
\hline \multicolumn{1}{c}{ Együttmüködés területe } & Magyar átlag & Osztrák átlag \\
\hline Kultúra (sport) & 33,6 & 28,1 \\
Gazdaság & 32,5 & 36,0 \\
Meglévő kapcsolatok ápolása & 10,2 & - \\
Idegenforgalom, turisztika & 9,7 & 14,2 \\
Infrastruktúra & 4,4 & 12,0 \\
Mezógazdaság & 3,7 & 7,0 \\
Területfejlesztés & 2,4 & - \\
Egyéb & 3,4 & 2,7 \\
\hline Összes & 100,0 & 100,0 \\
\hline
\end{tabular}

Forrás: Kérdóívek 1998. 
A gazdasági jellegủ kooperációs elképzelések mind magyar, mind osztrák oldalon megfigyelhetó magas aránya mutatja, hogy sajátos gazdaságtörténeti helyzet alakult ki e régióban, a térség gazdaságának aktív egymásra épülésére kínálkozik lehetőség. (Rechnitzer 1992)

A gazdasági együttmüködések legfontosabb keretfeltételeit a térségben ma már az ipari parkok teremtik meg: a szentgotthárdi, a szombathelyi és a soproni ipari park. Ezeket a városokat számtalan gazdasági érdekeltség köti össze Burgenlanddal, így többféle együttmúködés bontakozott ki közöttük. A legismertebb a Szentgotthárdi Ipari Park, amely a határ két oldalán helyezkedik el, s 1997-ben jött létre. A Szentgotthárdi Ipari Park egy határon átnyúló ipari park együttes, kapcsolódik hozzá a Heiligenkreuzi Ipari Terület Ausztriában. A tulajdonosi szerkezet úgy jellemezhető, hogy 70\%-ban egy ausztriai gazdasági társaság a Kft. tulajdonosa, 4\%-ban a szomszédos heiligenkreuzi önkormányzat, 24\%-ban a szentgotthárdi önkormányzat és 2\%-ban egy budapesti gazdasági tanácsadó cég (Tesco). Az osztrák oldali ipari parknak ugyanez a tulajdonosi szerkezete. Itt egy áttételen keresztül az osztrák tartomány, Burgenland a tulajdonos. A Burgenlandi Gazdaságfejlesztỏ Központnak 100\%-ban leányvállalata az az osztrák gazdasági társaság, mely a Kft. többségi tulajdonosa. A cég alaptőkéje 70 millió forint. A két ipari park kapcsolata a tulajdonosi szerkezetböl is következően egyre szorosabbá válik, a fỏ cél egy közös ipari park múködtetése.

A két ipari park számára fontos lenne egy vámmellékutas határátkelő megnyitása közúton és iparvágányon, hogy megvalósuljon a közvetlen kapcsolat a két ipari park, illetve a két ország között. A rábafüzesi határátkelő a teljesítőképessége határára érkezett, és gyakoriak a torlódások, s a just-in-time rendszerben dolgozó cégek nem engedhetik meg, hogy kamionjaik egy fél napot álljanak a határon. Azon cégek számára, akik nem rendelkeznek telephellyel egyik oldalon sem, egy logisztikai központon keresztül lehetne ezt lehetővé tenni úgy, hogy nem a parkon keresztül lépnék át a határt, hanem Rábafüzesnél, de egy külön kijelölt sávban.

A park területén müködő cégek nagyon polarizáltak, az egészen kicsi vállalkozásoktól kezdődően az olyan nagy cégekig, mint az Opel, vagy a Vossen. Új cégek is folyamatosan érdeklődnek a park iránt, mert jó a fekvése, infrastruktúrája. A magyar oldal olcsóbb, mint az osztrák ipari park, alacsonyabbak az energiaárak is. Osztrák oldalon viszont jelentősebbek a támogatások.

\section{Szombathely}

Szombathely hagyományos megyeszékhely, s ezt a státuszát megőrizte a határmegvonások után is. Önkormányzati kapcsolataira jellemző, hogy a határok megnyílása után a vonzáskörzetébe tartozó kisebb burgenlandi települések keresték meg együttmủködési szándékkal Szombathelyt.

Ezek a szándékok elsősorban a közös gazdasági, infrastrukturális érdekeltségeken alapulnak. A megyeszékhely testvérvárosa Oberwart (Felsőőr). A kapcsolatok 
kiterjednek közös kulturális rendezvényekre, eseményekre. Oberwart szempontjából nagy értéke van a szombathelyi repuilötérnek. A kis burgenlandi város elérhetöségét is nagyban javítaná a közeli repülőtér fejlesztése.

A másik közeli település Rechnitz (Rohonc). Itt az egyuittmúködés legfontosabb célja a megszüntetett, de még meglévỏ Szombathely-Rohonc vasútvonal felújítása, üzembe helyezése. Ezáltal a kissé elzárt burgenlandi területeket kapcsolnák be Szombathelyen keresztül a forgalomba. (Ebben a tárgykörben már konferenciát is tartottak a vasi megyeszékhelyen.)

\section{Fertöd}

Fertơd fiatal város a határ mentén. A határmentiségbỏl elsősorban az 1991-ben megnyitott határátkelő kapcsán profitál. Jelentősen megnỏtt a térségi turizmus, az átmenő forgalom, de ugyanakkor a Fertődöt céljául választó turisták száma is. Kapcsolatai a szomszédos területekkel meglehetősen szúk körre korlátozódnak. A személyes, rokoni, intézményi (iskola és egyház) kapcsolatok élök és gyakoriak. Hivatalos szinten is létezik kapcsolat, de együttmüködések kialakulásáról nincs tudomásunk. Inkább az osztrákok részéról megnyilvánuló egyfajta „féltékenykedésröl" számoltak be interjúink során a fertődi megkérdezettek. Már a határátkelő megnyitásakor adódtak problémák, mivel jelentős erỏk ellenezték azt, s a korabeli pamhageni (Pomogy) polgármester leváltásában is szerepet játszott a határátkelö szorgalmazása. Az ellenérzések oka a turisztikai és munkaügyi verseny megléte lehet (napi 2-2,5 ezer ingázó jár át a közeli területekre), a hasonló turisztikai kínálati struktúra (Eisenstadt).

Fertód és környéke kedvelt helye a burgenlandi és bécsi ingatlanvásárlóknak. Fertőd különleges helyet foglalt el a kárpótlási folyamatban. 1945-ig a terület Esterházy-birtok volt. Az államosítás során a terület 2/3-át az egykori cselédek, birtokon dolgozók kapták meg, a másik harmad továbbra is a kisparasztság kezében maradt. A ,cselédek" emocionálisan nem kötődtek már akkor sem a földhöz, szemben a parasztsággal, akik mindig is magukénak érezték földjuket. A késóbb megalakult állami gazdaság (cca. 2800 ha, TSZ cca.: 1600 ha) földjeit 1990 után újraosztották. A kárpótlás és licitálás során sok olyan új tulajdonos lett, aki továbbra sem kötődött a földhöz. Az egykori kisparasztok visszakapott tulajdonukat ma is megpróbálják megmủvelni, de az egykori ÁG földjei (cca. 2000 ha, megelözóen Esterházy-birtokok voltak) zsebszerzódésekkel, spekulációval mára osztrák tulajdonba kerültek.

Sopron vonzáskörzetében a határ menti területekkel komoly gazdasági kapcsolatok is kialakultak. Bécsújhelyi cégek a privatizáció során szereztek ingatlanokat, gyárakat, iuzemeket vásároltak meg Sopronban, s múködnek ma is. Ebben egy kicsit a városok közötti kapcsolat is benne van. A turizmus teruletén is jelentösek a kapcsolatok. A közeli térség nagy értéke a bor és a turizmus. Ezen a területen úgy tủnik, hogy komoly együttmúködés alakulhat ki, de még a kezdeteknél 
tartunk. Érdekes, hogy a környezỏ határ menti települések sorra jelentkeztek, jönnek és keresik a kapcsolatot, mert érzik, hogy az EU kapcsán, a csatlakozás után Sopronnak térségszervezỏ szerepe lesz, és inkább ide költöznének hosszabb távon, mint Bécsújhely, vagy Kismarton felé. Ez egyrészt földrajzi, másrészt történelmi adottságok miatt van így.

A gazdasági együttmüködések fö szervezöje az Ipari- és Kereskedelmi Kamara. A megalakulása óta törekszik arra, hogy kapcsolatot létesítsen Burgenlanddal, Eisenstadttal és Wr. Neustadttal, valamint a hatăr menti nagyobb településekkel. Tíz éve hivatalos a kapcsolat a tartománnyal, a tartományi kamarával és a politikai vezetéssel is.

A Soproni Vásár a rendszerváltás előtt nagyszámú burgenlandi vállalkozót vonzott. Azóta jellemzö, hogy amíg a lakosság számára rendezendő vásáron az osztrák résztvevők száma minimálisra csökkent, addig a szakvásárokon (faipari és erdészeti) folyamatosan nő az osztrák résztvevők aránya.

Mindkét irányban kiemelkedő arányú a kereskedelem a gazdasági együttmủködésben. Jelentős számú a magyar beszállító, főleg a gépiparban. Az ide települt osztrák cégek is az anyavállalataikkal állandó kapcsolatban vannak, emiatt fontos kérdés a határon való átlépés lehetősége és rugalmassága. Sok olyan cég van jelen a térségben, aki oda-vissza tart kapcsolatot. A téglaipar, a faipar, illetve a faipari alkatrészek piaca nagyon fontos kapcsolódási terület a gazdaságban, ahol Sopron szerepe egy térségi kereskedelmi központ lehet, mint egy erős faipari bázis.

$\mathrm{Az}$ együttmúködésre példa a közösen kidolgozott turisztikai stratégiai terv, $s$ kész tervek vannak a közös hulladékkezelésre, a víz, a gáz és a szennyvíz rendszer közös programban történő megszervezésére (pl. a gázrendszert könnyebb lett volna Ausztria felöl megoldani). Burgenland szívesen használná Sopron egyetemi infrastruktúráját is, mivel a tartományban nincs egyetemi oktatás, bár ennek kivitelezése egyelöre meghiúsult.

\section{Az együttmüködés intézményei}

Az együttmüködés intézményeit tekintve ez a térség az országban a leginkább fejlett, $s$ a legnagyobb hagyományokkal rendelkezö területnek mondható. Már a nyolcvanas években megtörténtek az első lépések az intézményi együttmüködés irányába, igaz - a kor szabályainak megfelelően - központi intézkedésként. Minisztertanácsi határozattal hozták létre 1985 októberében a Magyar-Osztrák Területrendezési és Tervezési Bizottságot (MOTTB). Az MOTTB célja az volt, hogy a közös határ menti területeken a partnerek informálják egymást a fejlesztési munkálatokról, tervekröl, esetleg közös fejlesztéseket hajtsanak végre. Mindkét oldalról a miniszteriális résztvevők mellett jelen voltak a magyar megyék (GyőrSopron, Vas és Zala) megyei tanácsának elnökei, és az osztrák tartományok (Burgenland, Alsó-Ausztria, Steiermark és Bécs) tartomány fönökei. A Bizottság háromszor ülésezett: 1986, 1988 és 1993-ban. Az operatív feladatok ellátására 
létrehozták a Magyar-Osztrák Területrendezési és Tervezési Albizottságot (MOTTA), melyen belül nyolc munkabizottság alakult.

A rendszerváltás után valósulhatott meg először olyan együttmüködés, melyben valóban csak az érdekelt felek, megyék, régiók vettek részt. Így 1992-ben megalakult a Magyar-Osztrák Határmenti Regionális Tanács, melynek tagjai Burgenland Tartomány, Vas és Győr-Moson-Sopron megyék, valamint Szombathely, Györ és Sopron megyei jogú városok lettek. A Regionális Tanács tagjai hosszú elökészítés után 1998 őszén alakították meg a West/Nyugat Pannónia Eurégiót, melynek kezdetben Burgenland Tartomány, Vas és Györ-Moson-Sopron megye lett a tagja, majd később Zala megye is csatlakozott hozzá (Rechnitzer 1997; 1998; 1999a; 1999b; 1999c; Hardi 1999; 2000).

1998-ban jött létre Mosonmagyaróvár környéki önkormányzatok kezdeményezésére a Kommunál Fórum, amely 13 magyar, 17 burgenlandi és 3 szlovákiai önkormányzat együttműködését biztosítja. A kis számú szlovák település részvétele mutatja, hogy bár hármashatár térségben jött létre az együttmủködés, mégis a magyar és osztrák túlsúly a jellemzỏ.

A térség területi egységei nagyobb regionális szerveződéseknek is a tagjai. GyőrMoson-Sopron megye és Burgenland tagja az Alpok-Adria Munkaközösségnek, mindkét oldal részt vesz a Duna menti Tartományok Együttmüködésében is.

A terület északi része a hármashatár, $\mathrm{s}$ az azt körülvevő fejlett régiók (két fövárosi tér: Pozsony, illetve Bécs közelsége, Burgenland felett északi része, s Magyarország dinamikus északkeleti területe találkozik) révén az egyik legígéretesebb együttmủködési területté vált. Ausztria EU csatlakozása után a hármashatár térség határ menti területei az osztrák oldalon EU külső határ menti térségnek, míg magyar és szlovák oldalon részben EU szomszédos ország határtérségnek, valamint EU-tól független határtérségnek számítottak. Ennek megfelelöen az együttmüködések finanszírozása is eltéröen alakult mind összegét, mind rendjét tekintve. Ausztria helyzetéböl adódóan ezen projekt-szintü együttmüködések esetében kulcspozíciót tölt be, így érthető, hogy a projektek számát, irányultságát és finanszírozását tekintve is az osztrák-szlovák és az osztrák-magyar irány dominál. A hármashatár térség projekt szintü együttmüködéseinek ezért az osztrák oldal vált a fö szervezöjévé. Bécs városa az INTERREG forrásaihoz jutva kívánja megvalósítani az 1994-ben, a városfejlesztési tervében megfogalmazott, határon átnyúló vonzáskörzet bővítési stratégiáját. Az ennek keretében megfogalmazott határon átnyúló projektekben együttmüködő partnerként veszi számba Györt és Pozsonyt.

A hármashatár térségben valósult meg az első, határon átnyúló stratégiai tervezési projekt, az Ausztria-Magyarország-Szlovákia Közös Hármashatár Fejlesztési Stratégia, melynek létrejöttét a PHARE CBC Szlovákia-Ausztria-Magyarország programja $^{3}$ támogatta. Célja, hogy a 2000-2006 közötti tervezési idöszakra osztrák oldalon az INTERREG III számára, míg szlovák és magyar oldalon a PHARE CBC számára keretprogramot, prioritásokat, s 10-12, már a programidőszak elején indítható programjavaslatot dolgozzon $\mathrm{ki}$ (Lados 2000). 
A nyugati határtérség együttmüködéseit a PHARE program alapozta meg. Az Európa Tanács az 1628/94. sz. határozatával hagyta jóvá a PHARE Cross Border Cooperation (PHARE CBC) programokat, mintegy az INTERREG II tükörprogramjaként, hogy támogatást biztosítson az Európai Unió külsó határainál kialakítandó határ menti együttmüködésekhez. Magyarország számára ez a forrás Ausztria EU csatlakozása után (1995) állt rendelkezésre.

Az osztrák-magyar PHARE CBC program forrásaiból Vas és Györ-MosonSopron megye részesedik, de bele került a körbe Zala megye is, mivel tagja a Nyugat-dunántúli régiónak, f́gy résztvevője a West/Nyugat Pannónia Eurégiónak is, bár a megelózö intézményeknek nem volt tagja. Mindez magyarázza, hogy a három megye közül Györ-Moson-Sopron és Vas 40-40\%-os, míg Zala megye 20\%-os arányban használhat fel uniós forrásokat az országhatáron átnyúló hatással is rendelkezö projektek finanszírozásához.

Az 1995-99-es időszakra Magyarország számára az Európai Unió Bizottsága 35 millió ECU felhasználását szavazta meg az osztrák-magyar PHARE CBC támogatás keretében, amit később 50 millióra emelt, amelyhez a magyar kormányzatnak ơt év alatt 11 millió ECU támogatást kellett biztosítania (5. táblázat).

\section{TÁBLÁZAT}

Az osztrák-magyar térségben rendelkezésre álló PHARE CBC források és azok felhasználási területei

(Available PHARE CBC Funds and Their Use in the Austrian-Hungarian Border Region)

\begin{tabular}{|c|c|c|c|c|}
\hline \multirow{2}{*}{ PROGRAMOK/PRIORITÁSOK } & \multicolumn{2}{|c|}{ Megoszlás (\%) } & \multicolumn{2}{|c|}{$\begin{array}{c}\text { PHARE támogatás összege } \\
\text { (euro) }\end{array}$} \\
\hline & Tervezett & $\begin{array}{c}\text { Meg- } \\
\text { valósulás* }\end{array}$ & Tervezett & $\begin{array}{c}\text { Meg- } \\
\text { valósulás* }\end{array}$ \\
\hline $\begin{array}{l}\text { PHARE CBC Magyarország- } \\
\text { Ausztria program 1995-1999 }\end{array}$ & 100 & 100 & 35000000 & 42000000 \\
\hline - Teruleti tervezés és fejlesztés & 10,4 & 3,4 & 3640000 & 1429000 \\
\hline $\begin{array}{l}\text { - Mủszaki infrastruktúra- } \\
\text { fejlesztés }\end{array}$ & 26,7 & 37,4 & 9345000 & 15716000 \\
\hline $\begin{array}{l}\text { - Gazdaságfejlesztés és } \\
\text { egyuittmủködés }\end{array}$ & 39,8 & 38,9 & 13930000 & 16319860 \\
\hline - Humán erőforrás-fejlesztés & 6,2 & 4,5 & 2170000 & 1887000 \\
\hline $\begin{array}{l}\text { - Környezet- és } \\
\text { természetvédelem }\end{array}$ & 11,8 & 9,9 & 4130000 & 4153041 \\
\hline - Kis Projektek Alapja & 5,1 & 3,4 & 1785000 & 1445100 \\
\hline $\begin{array}{l}\text { PHARE CBC Szlovákia- } \\
\text { Ausztria-Magyarország program } \\
1995-1996\end{array}$ & - & - & 3000000 & 2250000 \\
\hline $\begin{array}{l}\text { PHARE CBC Szlovénia- } \\
\text { Ausztria-Magyarország program } \\
1995-1996\end{array}$ & - & - & 3000000 & 3000000 \\
\hline Összesen & - & - & 41000000 & 47250000 \\
\hline
\end{tabular}

* A projektek sikeres szerzödéskötésének függvényében módosulhat.

Forrás: PHARE CBC PMU Soproni Iroda. 
A PHARE CBC program prioritásait a MOTTA (melynek feladata egyre inkább az INTERREG és PHARE CBC programok összehangolása), illetve a Határmenti Regionális Tanács (HRT) szakemberei határozták meg. A programok részben kapcsolódnak a megyék által kidolgozott területfejlesztési koncepciókhoz (Szörényiné Kukorelli 1999).

$\mathrm{Az}$ osztrák-magyar határ jelenleg az együttmüködések szempontjából a legfejlettebb határunknak tekinthetö. A határvonal, a schengeni rendelkezések miatt ugyan nehéz akadályt is jelent, de ezt messzemenően kompenzálja a hagyományos és széles körü együttműködések rendszere. A kapcsolatok tradicionálisak, s természetes földrajzi vonzáskörzet hálózaton nyugodnak. A korábbi térségi szerveződések újraélesztését nagymértékben szolgálta a már a nyolcvanas évek második felében kialakuló intézményrendszer, mely egyedülálló volt az országban, az 1995 után érkező uniós támogatások, melyek első célterülete ez a határszakasz volt. Ezeken az alapokon a magyar határok közül itt épültek ki a legszélesebb spektrumú együttmúködések, mind témájukat, mind intézményi formájukat illetően. Így ez a határ lényegesen előbbre jár az együttmüködések szervezésében a többi határunknál. Ennélfogva e kooperációknak közvetítő és mintaadó szerepe, jelentősége van/lehet az ország többi határ menti terủlete felé.

\section{Jegyzetek}

${ }^{1}$ Vizsgálatunkat 1998 nyarán folytattuk négy magyar telepullésen (Szentgotthárd, Fertöd, Levél, Zsira) és osztrák oldali párjukon (Heiligenkreuz, Pamhagen, Zurndorf, Lutzmannsburg). A lakossági kérdớivek felvételét polgármesteri interjúk, a regionális (megyei) sajtó tartalomelemzése, valamint csoportbeszélgetések egészítették ki. A kutatást magyar oldalon az MTA RKK Nyugat-magyarországi Tudományos Intézet, osztrák odalon az Österreichisches Ost- und Südosteuropa Institut munkatársai végezték. A továbbiakban is e felmérés eredményeire hivatkozunk.

${ }^{2}$ Hozzá kell tennünk, hogy a kikötőnek a fơldrajzi közelség ellenére nincs szlovák kapcsolata, söt jelentős konkurenciát fog jelenteni a $25 \mathrm{~km}$-rel lejjebb fekvö Észak-Komárom (Komarno) kikötöjének.

${ }^{3}$ A PHARE hármashatárra vonatkozó egyszeri programja, melyben 1,5-1,5 millió euró állt rendelkezésre magyar és szlovák oldalon. Az 1996. évi program középpontjában a határon átnyúló kommunikáció segítése állt. E program keretében támogatták a hármashatár térségére készùlö fejlesztési stratégia kidolgozását, mely 1999 januárjában indult a szlovák és februárjában a magyar oldalon (Lados 2000).

\section{Irodalom}

Baumgartner, G.-Kovács É.-Vári A. (2001) A határmentiség paradoxonai: Besenyőantal és Albrechtsdorf 1990-2000. Teleki László Intézet, Közép-Európa Tanulmányok Kózpontja, Institut Fừr Donauraum. Kézirat.

Csapó T. (1999) Határ menti együttmükỏdések a munkaeröpiac területén, különös tekintettel Vas és Zala megyére. - Nárai M.-Rechnitzer J. (szerk.) Elválaszt és összeköt - A hatăr. Gyớr-Pécs, MTA RKK. 269-295. o.

Döry T. (1999) Vállalkozások jövớképe az osztrák-magyar határ menti térségben. - Nárai M.-Rechnitzer J. (szerk.) Elválaszt és összeköt - a határ. Györ-Pécs, MTA RKK. 209-234. o. 
Erdősi F. (1988): A határ menti térségek kutatásáról. - Erdősi F.-Tóth J. (szerk.) A sajátos helyzetũ térségek terület- és településfejlesztési problémái. OKKFT Ts $-2 / 2$ „A terület- és településfejlödés társadalmi-gazdasági folyamatai Magyarországon” c. program, 2. sz. kiadvány. Pécs, MTA RKK. 18-30. o.

Hardi T. (1999) A határ és az ember - Az osztrák-magyar határ mentén élók képe a határról és a „,másik oldalról”. - Nárai M.-Rechnitzer J. (szerk.) Elválaszt és összeköt - A hatâr. Györ-Pécs, MTA RKK. 159-189, o.

Hardi T. (2000) Együttmüködések a szlovák-magyar dunai határ mentén. -Hardi T. (szerk.) A határ menti regionális együttmüködések mint a területfejlesztés üj irányai. Gyôr, MTA RKK NYUTI. (Kutatási jelentés).

Izsák É. (1999) A határmentiség és a határ menti regionális együittműködés a sajtó tükrében 1989-től napjainkig. - Nárai M.-Rechnitzer J. (szerk.) Elvalaszz és összeköt - a határ. Györ-Pécs, MTA RKK. 19l-207. o.

Kampschulte, A. (1999) Grenzraum und Systeme - Von geschlossenen zu offenen Grenzen? Tübingen, Geographischen Instituts der Universität Tübingen.

Kovács K.-Váradi M.M.(1996) Karöltve. A regionális együttmüködés esélyei a Bécs-Györ-Pozsony háromszögben. - Mühely. 3. 60-68. o.

Lados M. (2000) Példa a közös területi tervezésre. - Hardi T. (szerk.) A határ menti regionális együttmüködések mint a területfejlesztés új irányai. Györ, MTA RKK NYUTI. (Kutatási jelentés).

Nárai M. (1999) A határ mente mint élettér - A határmentiség jelentősége az emberek életében. - Nárai M.-Rechnitzer J. (szerk.) Elválaszt és összeköt - a határ. Györ-Pécs, MTA RKK. 129-158. o.

Nárai M.-Rechnitzer J. (szerk.) (1999) Elválaszt és összeköt-a határ. Györ-Pécs, MTA RKK.

Ormos M. (1997) Új rend a világban - Egy meghasonlott békerendszer. - Rubicon. 2. 13-19. o.

Rechnitzer J. (1992) A határmenti régiók megújítảsi lehetöségeinek néhány forrása. - Forray R.K.Pribersky, A. (szerk.), A határmenti együttmũködés és az oktatás. Budapest, Oktatáskutató Intézet. 119-125, o.

Rechnitzer J. (1997) Eurorégió vázlatok a magyar-oszrták-szlovák határ menti térségben. - Tér és Társadalom. 2. 29-58. o.

Rechnitzer J. (1998) A területi stratégiák. Budapest-Pécs, Dialóg-Campus Kiadó.

Rechnitzer J. (1999a) Bécs-Pozsony-Györ-Budapest innovációs tengely, s a magyar területfejlesztési koncepciók. Györ, MTA RKK Nyugat-magyarországi Tudományos Intézet. Kézirat.

Rechnitzer J. (1999b) Határ menti együttmüködések Európában és Magyarországon. Elválaszt és összeköt - a határ. - Nárai M.-Rechnitzer J. (szerk.) Györ-Pécs, MTA RKK. 9-72. o.

Rechnitzer J. (1999c) Az osztrák-magyar határ menti együttmüködés a kilencvenes években. - Nárai M.-Rechnitzer J. (szerk.) Elválaszt és összeköt-a határ. Györ-Pécs, MTA RKK. 73-127. o.

Rechnitzer J. (2000) A határ menti kapcsolatok fejlesztésének lehetséges irányai, ajánlások. - Hardi T. (szerk.) A határ menti regionalis egyuittmũködések mint a területfejlesztés új irányai. Györ, MTA RKK NYUTI. (Kutatási jelentés).

Rechnitzer J. (szerk.) (1990) Nyitott határ. (A gazdasági és szellemi erôforrások innováció-orientált fejlesztése az osztrák-magyar határ menti régiókban). Györ, MTA RKK Nyugat-magyarországi Tudományos Intézet.

Rechnitzer J. (szerk.) (1994) Fejezetek a regionális gazdaságtan tanulmányozásához. Györ-Pécs, MTA RKK.

Sallai J. (2001) Szomszédságban egy évezrede. - Bécsi Napló. Szeptember-október. 3. o.

Sári I. (2001) Györ és a vasutak. Györi Tanulmányok Fưzetek. Tudományos Közlemények. 6. Györ, Györ Megyei Jogú Város Levéltára.

Szörényiné Kukorelli 1. (1999) A női egyéni vállalkozások néhány jellemzöje a határ mentén. - Nárai M.Rechnitzer J. (szerk.) Elválaszt és összeköt - a határ. Győr-Pécs, MTA RKK. 235-267. o.

Teke A. (szerk.) (1999) Volt egyszer egy EJR. Györ, Györi Határör lgazgatóság. 


\section{THE TRANSFORMATION OF THE CHARACTERISTICS OF BORDER REGIONS AT THE END OF THE $20^{\mathrm{TH}}$ CENTURY IN WEST HUNGARY}

\section{TAMÁS HARDI - MÁRTA NÁRAI}

The western border of Hungary, the Austrian-Hungarian state border was borned in the frame of the peace-treaty end the first World War similarly the other borders of the country. However there are significant differences in its historical process and the main characteristics. Between the wars, when the surrounding countries, newly formed or transformed nation-states aimed at increasing the separating role of the new border, the border between Austria and Hungary didn't hinder the continuation of everyday relations. Under the socialism this borderline became the separator obstacle of two big world system. The strictly defend western border regions missed from the important development programmes and former traditionally well-developed regions came to peripheral situation. After the system transformation in 1989-1990 the location of the region became more significant again and now considerable part of the Austrian-Hungarian border region became front-rank area of Hungarian development. This study likes to present the changes of the last decade on the basis of the results of earlier researches. It contains the transforming economy in comparison to the developing trends of the neighbouring Austrian areas (Burgenland), the transforming society, the changing cross-border co-operation and the future possibilities. 